\title{
Industrial Location, Relations with Regional Agents, Formation and Innovation in Spanish Aquaculture
}

\author{
Francisco Javier Sánchez Sellero', Montserrat Cruz González², Pedro Sánchez Sellero³
}

\begin{abstract}
This paper tries to contrast theories and location factors with the results of an open investigation on management of intellectual capital in aquaculture. We analyse the applicability of endogenous development models and enterprise networks, from an alternative point of view different from the hierarchy and the market, finally theories about the formation weight and the R\&D\&i efforts in real investments and real expenditures that the spanish aquaculture companies assume are contrasted, in competitiveness terms.
\end{abstract}

Keywords: R\&D\&i.; aquaculture; endogenous development models; enterprise networks; competitiveness; industrial location; relations with regional agents; formation.

\footnotetext{
' Universidad de Vigo, Departamento de Organización de Empresas y Marketing, Facultad de Ciencias Económicas y Empresariales, Campus Lagoas-Marcosende, 363 I 0,Vigo (Pontevedra), Spain. Phone: +349868 I2489, +346 I887I 965. Email: javiss@uvigo.es ${ }^{2}$ Universidad de Vigo, Departamento de Organización de Empresas y Marketing, Facultad de Ciencias Económicas y Empresariales, Campus Lagoas-Marcosende, 363 I0,Vigo (Pontevedra), Spain. Phone:+349868I2476,+34606914I57. Email:mcruz@uvigo.es

${ }^{3}$ Universidad de Zaragoza, Departamento de Dirección y Organización de Empresas, Centro Politécnico Superior, Edificio Betancourt, Campus Río Ebro, 500 18, Zaragoza, Spain. Phone: +34976761000-ext:5265, +34625725727. Email:pedross@unizar.es
} 


\section{Introduction and Proposal of Theoretical Models}

The localization decision has particular and differentiated characteristics in regards to other management decisions, it may generally be defined as complex, dynamic, influence, infrequent and subjective (Domínguez, 1995; Schmenner, 1982; Aydalot, 1985; Laulajainen and Stafford, 1995). In addition, the assumptions of perfect rationality which is based on the Theory of Industrial Location (Smith, 198I); another set of trends takes into consideration issues related to human factor, the environment and the characteristics of the firm. At the same time, as opposed to concepts purely rational, quantitative and strategic that causes the locacional decision referred in classic and prolific papers in the first half of the 20th century, such as the spatial margins of profitability by Rawstron, the management matrix by Pred, the spatial distribution of the demand proposed by Greenhut, market areas of Lösch, the basic location triangle by Weber, the interdependence location by Hotelling or reticulated location of services through hexagonal areas and the demand cones by Christaller; it is evidenced that the location of industrial establishments depends increasingly on subjective and psychological factors, (the literature of the "psychic incomes" has been referred to by multiple authors, of which we emphasize the most current one by Malecki, 1991; 1996; so later studies are based on concentrations of high-technology industries or "cities of science" -see Saxenian, 1990; Precedo and Villarino, 1992; Castells and Hall, 1994; Maillat, 1995; Porter, 1999-), as well as behavioral or linked to previous "accidents" factors according to the qwerty theory - see references to the family tradition or the activity in the area, the simple owner's dwelling place, the contacts with suppliers or local distributors or the minimization of the risks (Aurioles and Pajuelo, 1988; Chapman and Walker, 1990; Arthur, 1994; Krugman and Obstfeld, 200I; Viladecans, 2004).

In relation to current paradigmatic theories about location we make reference to the approach of marshalliana industrial districts, to later continue with neoclassical and neo-weberianos models and normative theory. Also, we must echo the dependency theories and the regional development theories (see circular and cumulative causation, unbalanced development and center-periphery model, economic linkages or the theory of the spatial division of labor), particularizing our exegesis in the school of behavior, the structuralist and the assimilated territorial development theory, the endogenous regional development models in the first current expression after Marshall (italian district) and the Coase-Williamson-Scott paradigm and the metropolitan economy. Therefore the analysis is focused on the explanation of the spatial distribution of resources and the production, or in other words, the study of the place where economic activity is evidenced and the reasons followed in order to determine the geographical location. According to this objective, causes and/or consequences of historic-temporary and physical-territorial nature will be evidenced (in particular, the approach of the circular and cumulative causation of Myrdal, referredtointhis dynamic"surrounding"oflocation).

As regards to the competitiveness of local productive systems, its main characteristic feature is found in the organization of the production; defined by the presence of specialized companies networks, so that their economic viability is achieved by the generation of externalities and the reduction of transaction costs. Local production systems constitute a production model dominated by corporate networks (formed by agents or actors, resources, economic activities and their relations -Hakansson and Johanson, 1993-) and domestic exchange products markets, services and knowledge (Costa, 1988; Becattini, 1997; Vazquez, 1999); in this kind of market relations are established based on mutual trust (Ottati, 1996) that strengthens the benefits of exchange itself (allowing minimizing the risk of random moral, if we analyze such relations on the basis of the agency theory), where cooperative and competitive roles among companies are intermixed (Piore and Sabel, 1984). Industrial networks are combined with the market and hierarchies, to regulate the productive systems, allowing the reorganization of internal relations motivated by the market, the innovation and the correlation of forces among participants (Hakansson and Johanson, 1993). The economic growth and the increasing returns are necessarily supported by the exploitation of externalities to contribute to a better regional welfare, the drag and motoric theory and the theoretic proposals of "growth poles", with its recommendations about the priority to basic and intermediate industries by the multiplicity of their linkages, shackles, motoric and dependence; in this case, Romer (1986, 1994) and Krugman (1998), referred to in the theory of the great development on the basis of the exploitation of economies of scale. 
However,Becattini(1997)differentiates between thesearch of significant size (theory of the great development) and the intrinsic relations and exchanges to the business systems under the model referred (endogenous development); while Otatti (1996) adds knowledge and mutual trust as a contribution for endogenous development, wich conciliates both approaches in relation to the network relations which allows the exchange of products, services, technological knowledge and patterns of behavior. Finally, Piore and Sabel (1984) and Hakansson and Johanson (1993), categorize the model of endogenous development by the mixture of cooperation and competition and the expression of the industrial network as a formula for regulation and stability for the production system. The corporate competitiveness, should be measured by the capability to generate value and a profitability of the invested capital equal or higher than their opportunity cost; such capability is conceived as a dynamic and comparative reality with other companies, characterizing and defining, in a permanent way, open markets (Cuervo, 1994: 363). In short, initially competitiveness makes sense at a corporate level, presenting different problems when adding levels of competition and trying to define competitiveness space patterns or factors (either local, regional or national).

The competitive success or failure, will be addressed from the Theories of the Strategic perspective, and it must combine both company, market and institutional environment as units of analysis of the factors of business competitiveness. Thus, the companies that will pretend to meet the challenges of competitiveness, should bear in mind the turbulent environment characteristics and the changes in the strategic paradigm, generators of technology gaps between business strategies and domestic resources (Porter, 1995, 1999; Hall, 1993; Bueno, Morcillo and Salmador, 2006; Yoshino and Rangan, 1995: 95-97; Grant, 1996; Johnson and Scholes, 1996; Edvinsson and Malone, 1997), so that companies will seek new production technologies, which make possible improvement of the costs (by means of a better control of storehouse, a bigger capability to respond to changes in the demand through flexible manufacturing systems, and not its anticipation and the rationalization in the consumption of raw materials). Companies will endeavour to apply new technologies of marketing to improve the brand image, the joint use of process and product technologies for the achievement of bigger degrees of quality, the origin of new technology capabilities to present the virtuality to optimize the flexibility of their production systems and adaptation to the environment, while new product technologies will require renewed efforts on the decisions of differentiation (Richardson, 1984).

\section{Material and Methods}

Particularizing our analysis in the location studies, we assert that they are one of the most relevant assets in the field of geography economic, therefore our approximation to the discipline can differentiate multiple types of research, forms of explanation or purposes, such as: the scientific interest, business demands and the prescriptive objective. Based on an analysis about theories of industrial location, as well as similar researches carried out by Townroe (1972: 26I-272), Aurioles and Pajuelo (1988: 198), Cotorruelo and Vazquez (1997: 17I-214), Galán, Suárez and Zúñiga (1998: 159), Gómez (2001), Trueba and Lozano (200I), Arauzo (2002), Davis and Weinstein (2002), Forslid, Haaland and Midelfart (2002), Rieber and Tran (2002), McCann and Sheppard (2003, 2004), Guimaraes, Figueiredo and Woodward (2004), Kakamu and Fukushige (2004), Arauzo and Manjón (2004), Viladecans (2004), Amiti (2005), Wood and Parr (2005), and so on, we have chosen to distinguish eight big groups of factors that explain the location decision: factors of production and cost, which are strategic and linked to the industrial atmosphere (related to the theoretical characterization about Marshall's industrial districts), referred to regional characteristics, sector competitiveness in the region, normative and public initiative, subjective factors and urbanization economies outside the sector. All of them will be used to contrast the existence of patterns of locational behaviour and the virtual implementation of the different theories about industrial location initially exposed. Additionally, and in an effort to try to contrast the main theoretical models regarding competitiveness, the endogenous regional development and business networks, we propose a comparative analysis about average spreads, by autonomous communities and activities developed with which to indicate rules or patterns about competitiveness, relations with third parties and strategic alliances, conditionalities and typologies about the location decision, efforts in training, technology and innovation in the Spanish aquaculture. 


\section{Results}

Now we do a descriptive analysis, comparison of average and principal components factorial analysis about the differentiated territorial behaviour of aquaculture firms in Spain, from a statistically significant sample obtained by a field research between October of 2006 and May of 2007. Our study has been focused on the Spanish aquaculture sector in a broad perspective, which included manufacturing companies, their main suppliers and the commercial firms, obtaining as a result a target group of 748 companies that we have selected following representativeness criteria from multiples databases (Public, Jacumar, Sabi, Ardán, Pesca2, Acui2006...), getting a sample size of 95 firms (response rate $12.7 \%$ ), assuming a sample error $\pm 8.8 \%$ and a confidence level of $95 \%(z=1.96)$.

Firstly, we have found convenient to implement the principal factorial analysis components to prove the potential existence of informer criteria of the location decision. In this way, we have defined patterns of global industrial location for the whole of companies, which are independent from the territory or the consideration of manufacturing firm, supplier or commercial firms; observing a first factor or component that explains about $30 \%$ of the variance and that is related to the regional circumstantial (atmosphere, specialization, sector competitiveness, proximity and infrastructures), even when some bias in the use of the scale by the managers is also evidenced; a second explanatory component of $13.7 \%$ of the variance alludes to the theories of the accident or qwerty - locational subjectivity - the third relates to the regulation, residence and strictly economic factors - cost of production and availability of floor, while the fourth component shows the impact of the infrastructures and the fifth one the distinctiveness of each company and to a lesser extent proximity criteria with the main agents -suppliers and distributors- (see tables I and 2 attached), to evidence simultaneously remarkable differences in regards to the valuation of the multiple potential location factors and explanatory global theories of aforementioned decision according to activities, types of cultivation and territorial register.

\begin{tabular}{|c|c|c|c|}
\hline \multirow{2}{*}{ Component } & \multicolumn{3}{|c|}{ Sums of the square saturation of extraction } \\
\cline { 2 - 4 } & Total & \% of the variance & $\%$ accumulated \\
\hline $\mathbf{1}$ & 4,310 & 28,734 & 28,734 \\
$\mathbf{2}$ & 2,062 & 13,747 & 42,481 \\
$\mathbf{3}$ & 1,573 & 10,490 & 52,971 \\
$\mathbf{4}$ & 1,364 & 9,095 & 62,066 \\
$\mathbf{5}$ & 1,310 & 6,732 & 68,798 \\
\hline
\end{tabular}

Table I. Total Variance Explained by factorial analysis (I5 Variables of location)/* Extraction Method: Principal Components Analysis. 


\begin{tabular}{|l|c|c|c|c|c|}
\hline \multicolumn{1}{|c|}{ Determinants Factors of the Location Decision } & \multicolumn{5}{c|}{ Component } \\
\cline { 2 - 6 } & 1 & 2 & 3 & 4 & 5 \\
\hline Production Factors and its Cost & 0,378 & $-0,623$ & 0,335 & 0,043 & 0,191 \\
Availability of industrial land & 0,435 & $-0,318$ & 0,426 & $-0,403$ & $-0,433$ \\
Ease supply by road and rail & 0,460 & $-0,295$ & 0,143 & 0,568 & $-0,369$ \\
Industrial infrastructure in general & 0,676 & $-0,104$ & $-0,178$ & 0,344 & $-0,119$ \\
Proximity to materials and/or to the majority of the suppliers & 0,757 & 0,090 & $-0,095$ & 0,167 & 0,324 \\
Proximity to customer/s products transformer company & 0,539 & 0,062 & 0,243 & 0,273 & 0,307 \\
Industrial atmosphere in the region & 0,710 & $-0,015$ & $-0,472$ & 0,186 & $-0,184$ \\
Productive Specialization linked to industry in the region & 0,687 & 0,225 & $-0,196$ & $-0,276$ & $-0,062$ \\
Sector Competitiveness in the region & 0,693 & 0,240 & $-0,182$ & $-0,261$ & $-0,082$ \\
Normative and Public Initiative & 0,507 & $-0,286$ & 0,461 & $-0,295$ & $-0,189$ \\
Owner's place of residence & 0,109 & 0,700 & 0,487 & 0,161 & $-0,026$ \\
Local Origin of the company & 0,315 & 0,705 & 0,328 & 0,274 & $-0,110$ \\
Tradition of the activity in the area & 0,471 & 0,417 & 0,060 & $-0,516$ & 0,158 \\
Unique Characteristics of the company & 0,361 & $-0,304$ & 0,288 & $-0,004$ & 0,558 \\
External Economies of Urbanization & 0,519 & $-0,137$ & $-0,471$ & $-0,154$ & 0,085 \\
\hline
\end{tabular}

Table 2. Matrix of Components / * Extraction Method: Principal Components Analysis. (5 components extracted)

In regard to relations with commercial agents in the region, we show the figure I that evidences a majority of companies whose regional operational do not reach the fourth part of its operations of resources provision and derivation of finished products, while we also stress how a third part of the aforementioned companies operate principally with regional operators (dedicating more than $75 \%$ of their buys and sales to regional operators). Territorial means are compared to stress the important relations with regional operators in Galician firms, the minimum impact in Catalonia and Valencian Community; while in sectors and in activities we have to emphasise the regional "adaptation" of manufacturing firms to their customers and commercial firms in terms of their suppliers (see table 4).

In reference to the participation of the regional technical colleges in the sector development, its impact in Catalonia, Andalusia and Galicia stands out from the rest and its contribution remains minimal, as it is understood in aquaculture firms, in Castile-León and Valencian Community. In fact Andalusian firms value the fluidity of relations and cooperation of the different regional social agents in the endogenous development of the sector extremely, in contrast with the indifference exhibited in the Valencian Community's companies. The private policies decision's taking of training and spending on aforementioned items in regard to the billing is particularly high in the Andalusian companies and in the suppliers subsector; and lower in Galicia and Castile-León, as well as in commercial firms; on the other hand, the spending on R\&D\&i and the proportion of researchers is higher in the Valencian Community, Galicia and globally, in suppliers, being less in Catalonia and traders.

The propensity to the signing of agreements is higher in Andalusia and Catalonia and lower in distribution and commercial firms. The temporary job level of human resources is significantly higher in Catalonia, Galicia and manufacturing firms and differentially lower in Andalusia and suppliers firms. Subcontracting and outsourcing activities, as an alternative to the internal incorporation, is higher in Galician aquaculture firms and, differentially 
higher in the suppliers, while being the aforementioned possibility in the Valencian Community and in commercial and distribution firms barely considered. It is not observed statistically significant differences in regard to differentiated behaviour, by territories or activities. In terms of rationality or irrationality location; but the environment of the establishment, mainly rural in manufacturing firms, Galician and Castilian-Leonese is registered and preferably intermediate in Catalonia as well as suppliers and distributors. Finally, the Andalusian and Castilian-Leonese firms, as well as globally manufacturing firms implement a higher level of technology surveillance systems (the summary of averages is presented in table 3 and 4 , even when we support our assertions in individual hypothesis contrasts with the implementation of KruskalWallis $h$ test, which we do not attach to avoid redundancy).

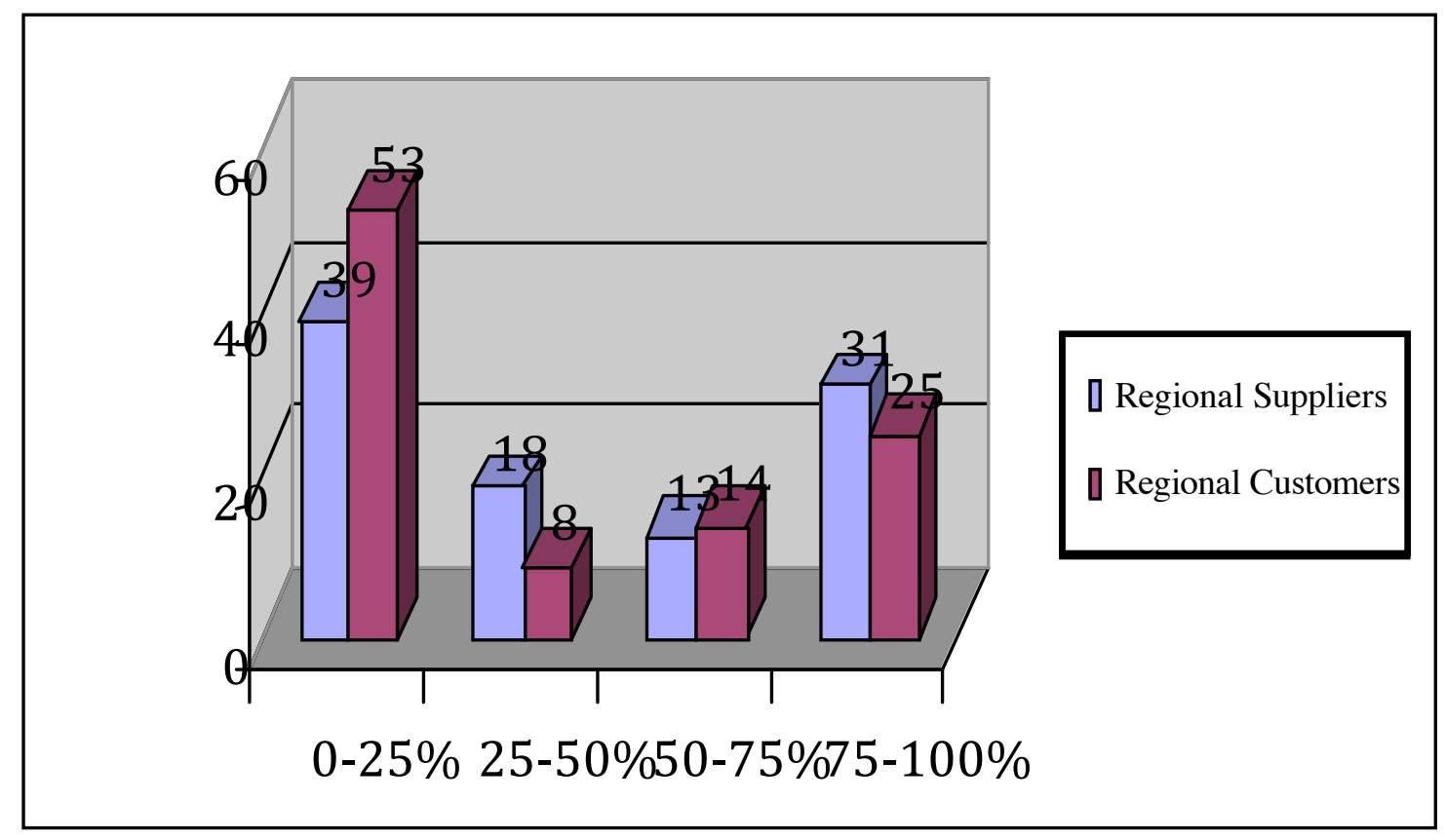

Figure I. Trade Relations in the Region

\begin{tabular}{|c|c|c|c|c|c|c|c|}
\hline & $\begin{array}{c}\% \text { Aquaculture } \\
\text { Firms }\end{array}$ & $\begin{array}{l}\text { \%Formation } \\
\text { Expenditure }\end{array}$ & $\begin{array}{c}\text { Average } \\
\text { Researcher }\end{array}$ & $\begin{array}{l}\text { \%R\&D\&i } \\
\text { Expenditure }\end{array}$ & Temp. & $\begin{array}{c}\text { Development of } \\
\text { Surveillance } \\
\text { Systems }\end{array}$ & $\%$ Subcontracting \\
\hline Galicia & $44,21 \%$ & 0,94 & 7,05 & 4,94 & 17,69 & 2,00 & 4,30 \\
\hline Castile-León & $10,53 \%$ & 1,05 & 6,50 & 2,80 & 8,60 & 2,50 & 2,50 \\
\hline Andalusia & $9,47 \%$ & 3,44 & 4,17 & 3,28 & 5,89 & 2,56 & 1,33 \\
\hline Catalonia & $8,42 \%$ & 1,75 & 2,88 & 1,63 & 22,88 & 2,25 & 2,50 \\
\hline Valencian Com. & $6,32 \%$ & 2,00 & 14,25 & 4,67 & 13,17 & 1,83 & 0,33 \\
\hline Producers & $74,74 \%$ & 1,63 & 6,70 & 3,92 & 16,23 & 2,38 & 3,41 \\
\hline Suppliers & $13,68 \%$ & 2,15 & 10,92 & 8,62 & 7,23 & 2,08 & 8,35 \\
\hline Commercialisation & $11,58 \%$ & 0,59 & 2,27 & 1,05 & 12,73 & 1,82 & 0,45 \\
\hline Total & $100 \%$ & 1,58 & 6,77 & 4,23 & 14,59 & 2,27 & 3,74 \\
\hline
\end{tabular}

Table 3. Regional Comparative on Aquaculture Firms 


\begin{tabular}{|l|ccccccc|}
\hline & $\begin{array}{c}\text { \% Prov. } \\
\text { Region }\end{array}$ & $\begin{array}{c}\text { \% Customers } \\
\text { Region }\end{array}$ & $\begin{array}{c}\mathrm{N}^{\text {o }} \\
\text { agreements }\end{array}$ & $\begin{array}{c}\text { Technical } \\
\text { Schools } \\
\text { Collaboration }\end{array}$ & $\begin{array}{c}\text { Agents Reg. } \\
\text { Collaboration }\end{array}$ & $\begin{array}{c}\text { Location } \\
\text { Rationality } \\
\text { Level }\end{array}$ & Environment \\
\hline Galicia & 64,89 & 55 & 0,57 & 0,60 & 1,81 & 0,60 & 2,67 \\
Castile-León & 45,50 & 46 & 0,40 & 0,20 & 2,10 & 0,60 & 2,80 \\
Andalusia & 40,00 & 43 & 0,89 & 0,78 & 2,44 & 0,56 & 2,44 \\
Catalonia & 20,63 & 33 & 0,88 & 0,88 & 2,13 & 0,63 & 2,13 \\
Valencian Com. & 36,17 & 36 & 0,50 & 0,17 & 1,50 & 0,67 & 2,33 \\
\hline Producers & 49,13 & 48 & 0,65 & 0,49 & 1,89 & 0,62 & 2,66 \\
Suppliers & 38,88 & 40 & 0,62 & 0,69 & 1,85 & 0,46 & 2,15 \\
Commercialisation & 65,45 & 21 & 0,27 & 0,55 & 2,09 & 0,64 & 2,18 \\
\hline Total & 49,62 & 44 & 0,60 & 0,53 & 1,91 & 0,60 & 2,54 \\
\hline
\end{tabular}

Table 4. Regional Comparative in Relation to the territory and Locational Determinants

\section{Discussion}

We have characterized five components on the grounds of principal components factorial analysis, that are ordered as follows, regional circumstances, subjective considerations, regulation, place of residence and production factors, infrastructures impact (transport and industry in general) and unique characteristics of the companies and proximity to operators (suppliers and customers); also we have managed to identify specific patterns of territorial and sector characters, as well as activities and cultivation typology. Suppliers firms are distinguished by a high investor effort in training and research (due to a high technological component and spillover effect on the production activity processes, low impact on the territory, a use of subcontracting and reaping of the benefits derived from the signing of agreements and alliances with third parties and the contribution of regional technical colleges, while the commercial firms barely invest in training or R\&D\&i -even in its commercial side-, the positively value the implication of the regional stakeholders and they basically buy from regional operators; finally, manufacturing firms distribute predominantly through regional operators, the possibility of successive labour reforms to bring its employees to the sector conjuncture exploit better, applying technology surveillance systems in rural habitats in a high level. The Galician firms are fundamentally characterized by regional operators, being its comparative spending in training very low, which contrasts with a bigger effort in research, a higher level of temporary job, the presence of regional technical colleges and subcontracting; the level of competitiveness of Castilian-Leonese firms seems low because of its contribution in terms of technical schools. Researcher profile and signing of agreements and alliances with third parties are low too, which contrasts with a bigger monitoring of technology surveillance systems; the Andalusian firms are especially highlighted by its differential spending in training, signing of agreements, the presence of technical schools, collaboration of regional agents, surveillance systems and minimum temporality. The Catalonian firms barely interact with suppliers and regional distributors, presenting a low researcher profile, being the location decision near to the optimal, high temporality, signing of alliances and participation of technical schools, whereas Valencian aquaculture firms are highlighted by its researcher profile -employees and spending- and low or near to zero participation of the regional agents in the sector development. In any case, we have to analyze with remarkable caution the territorial conclusions, as they are strongly correlated with their differential activities, their innovative component, the type of cultivation or the requirements of investment in capital and human resources. 


\section{References}

AMITI, M. (2005). Location of vertically linked industries: agglomeration versus comparative advantage, European Economic Review, 49, iss. 4, pp. 809-832.

ARAUZO, J.M. (2002). Determinants of industrial location. An application for catalan municipalities. Estudios sobre Economía Española, 138. FEDEA.

ARAUZO, J.M. and Manjón, M.C. (2004). Firm size and geographical aggregation: an empirical appraisal in industrial location, Small Business Economics, 22, iss. 3-4, pp. 299-312.

ARTHUR, B. (1994). Increasing returns and path dependence in the economy, Ann Arbor, University of Michigan Press.

AURIOLES, J. and Pajuelo, A. (1988). Factores determinantes de la localización industrial en España, Papeles de Economía Española, n 35, pp. 188-207.

AYDALOT, P. (1985). Economie régional et urbaine, París: Ed. Económica.

BECATTINI, G. (1997). Totalità e cambiamento: il paradigma dei distretti industriali, Sviluppo Locale, vol. IV, $\mathrm{n}^{\circ}$ 6, p. 5-24.

BUENO,E., Morcillo,P.andSalmador,M.P.(2006).Dirección Estratégica: Nuevas Perspectivas, Edit. Pirámide, Madrid.

CASTELLS, M. and Hall, P. (1994). Las tecnópolis del mundo. La formación de los complejos industriales del siglo XXI, Alianza, Madrid.

CHAPMAN, K. and Walker, D. (1990). Industrial location. Principles and policies, Blackwell, Oxford.

COSTA, M. T. (1988). Descentramiento productivo y difusión industrial. El modelo de especialización flexible, Papeles de Economía Española, núm. 35, p. 25I-276.

COTORRUELO, R. and Vázquez, A. (1997). Nuevas pautas de localización de las empresas industriales y de servicios a las empresas en España, en Vázquez, A., Garofoli, G. and Gilly, J.P.: Gran empresa y desarrollo económico, Síntesis, Madrid, Pp. I7I-2I4.
CUERVO, A. (1994). Análisis y planificación financiera de la empresa, Civitas, Madrid.

DAVIS, D.R.; Weinstein, D.E. (2002). Bones, bombs and break points: the geography of economic activity, American Economic Review, n 92, p. 1269-89.

DOMÍNGUEZ, J.A. (1995). Dirección de operaciones, aspectos estratégicos en la producción y los servicios, McGraw-Hill, Madrid.

EDVINSSON, L. and Malone, M.S. (1997). Knowledge management at Skandia, The knowledge challenge conference, MCE, Bruselas.

FORSLID, R., Haaland, J. I. and Midelfart, K. H. (2002). A u-shaped Europe? A simulation study of industrial location, Journal of International Economics, 57, iss. 2, pp. 273-297.

GALÁN, J.I., Suárez, I. and Zúñiga, J.A. (1998). Factores determinantes de las decisiones de localización en España, Economía Industrial, 320, pp. I5I-I64.

GÓMEZ, J.S. (200I). El marco decisional en la selección del emplazamiento de la industria. Características y particularidades de las decisiones de localización, Investigaciones Europeas de Dirección y Economía de la Empresa, $n^{\circ} 7(1)$, pp. II7-134.

GRANT, R. (1996). Dirección Estratégica: Concepto, técnicas y aplicaciones. Civitas, Madrid.

GUIMARAES, P., Figueiredo, O. and Woodward, D. (2004). Industrial location modelling: extending the random utility framework, Journal of Regional Science, 44, I, I-20.

HAKANSSON, H. and Johanson, J. (1993). The network as a governance structure. Interfirm cooperation beyond markets and hierarchies, en G. Grabher (eds.), The embedded Firm. On the socioeconomics of industrial network, Routledge, Londres.

HALL, P. (1993). Forces Reshaping Urban Europe, Urban Studies, 30 (6).

JOHNSON, G. and Scholes, K. (1996). Dirección Estratégica, Prentice Hall, Madrid. 
KAKAMU, K. and Fukushige, M. (2004). Economics of agglomeration and the three laws governing industrial location in Kansai Area, Studies in Regional Science, 34, iss.3, pp. 25I-260.

KRUGMAN, P. (1998). What's new about the new economic geography?, Oxford Review of Economic Policy, I4 (2).

KRUGMAN, P. and Obstfeld, M. (200I). Economía internacional: teoría y política, Addison-Wesley, Madrid.

LAULAJAINEN, R. and Stafford, H.A. (1995). Corporate geography. Business location, principles and cases, Kluwer Academic Publishers, Dordrecht.

MAILLAT, D. (1995). Milieux innovateurs et dynamique territorial, en Rallet, A. y Torre, A. dirs., Economie industrielle et économie spatiale, Economica, París, p. 2II-23I.

MALECKI, E.J. (I99I). Technology and economic development: the dynamics of local, regional and national change, John Wiley, Nueva York.

MALECKI, E.J. (1996). Technology, competitiveness and flexibility: constantly evolving concepts, en Knudsen, D.C. The transition to flexibility, Kluwer Academic Publishers, Boston.

MCCANN, P. and Sheppard, S. (2003). The rise, fall and rise again of industrial location theory, Regional Studies, 37, iss. 6-7, pp. 649-663.

MCCANN, P. and Sheppard, S. (2004). Location, agglomeration and infrastructure, Papers in Regional Science, 83, 177-196.

OTTATI, G. D. (1996). El distrito industrial y el equilibrio entre cooperación y competencia, Información Comercial Española, Junio, p. 85-95.

PIORE, M.J.; Sabel, C. (1984). The second divide. Possibilities for prosperity, Basic Books Inc., Nueva York (edición española: La segunda ruptura industrial, Alianza, Madrid, 1990).

PORTER, M. (1995). The competitive advantage of the inner city, Harvard Business Review, vol. 73, n 3, pp. 55-7I.

PORTER, M. (1999). Ser competitivos, Ed. Deusto, Bilbao.
PRECEDO, A. and Villarino, M. (1992). La localización industrial, Síntesis, Madrid.

RICHARDSON, H. (1984). The regional policy in a slowgrowth economy, en G. Demko (ed.), Regional Development. Problems and policies in Eastern and Western Europe, Croom Helm, Londres.

RIEBER, A. and Tran, T. A. (2002). Technology difusión, north-south spillovers and industrial location, Journal of Economic Development, 27, iss. I, pp. 25-39.

ROMER, M.P. (1986). Increasing returns and long run growth, Journal of Political Economy, vol. 94, p. 1002-1037.

ROMER, M.P. (1994). The Origins of Endogenous Growth, The Journal of Economic Perspectives, vol. 8, p. 3-22.

SAXENIAN, A.L. (1990). Regional networks and the resurgence of Silicon Valley, California Management Review, $n^{\circ} 33$, pp. 89-III.

SCHMENNER, R.W. (1982). Making business location decisions, Prentice Hall, Englewood Cliffs, New York.

SMITH, D. (198I). Industrial location. An economic geographical analysis, John Wiley and Sons, New York.

TOWNROE, P.M. (1972). Some behavioural considerations in the industrial location decision, Regional Studies, $n^{\circ} 5$, p. 26I-272.

TRUEBA, M. C. and Lozano, P. (200I). Las pautas de localización industrial en el ámbito municipal: relevancia de las economías de aglomeración, Economía Industrial, 337, Pp. 177-188.

VÁZQUEZ, A. (1999). Desarrollo, redes e innovación: lecciones sobre desarrollo endógeno, Pirámide, Madrid.

VILADECANS, E. (2004). Agglomeration economies and industrial location: city-level evidence, Journal of Economic Geography, 4, iss. 5, pp. 565-582.

WOOD, G.A. and Parr, J.B. (2005). Transaction cost, agglomeration economies and industrial location, Growth and Change, 36, iss. I, Pp. I-I5. 
YOSHINO, M.Y. and Rangan, U.S. (1995). Strategic alliances. An entrepreneurial approach to globalization, Harvard Business School Press, Boston (spanish edition: Las alianzas estratégicas. Un enfoque empresarial a la globalización, Ariel, Barcelona, 1996). 